\title{
Az alkalmazottak fluktuációjának és munkaerőhiányának elemzése a közszférában egy országos empirikus kutatás tükrében
}

\section{Bevezetés}

Jogos a kérdés. Miért foglalkozunk a fluktuáció és a munkaerőhiány kérdéseivel egy olyan országban, ahol még öt évvel ezelőtt is kétszámjegyú $(10,2 \%)$ volt a munkanélküliség (KSH, 2018).

Sokáig csak olyan előrejelzésekkel és gondolatokkal találkoztunk szembe, hogy kevés a munkahely, az embereknek vigyázni kell a meglévő állásukra, becsüljék meg, hogy van munkájuk, mert ha azt elveszítik, akkor általában véve nehéz lesz új munkát találni illetve számolni kell a munkanélküliség fenyegetésével is.

Különösen igaz volt a fiatal pályakezdőkre, az ötvenévesnél idősebb korosztályra, a kistelepülésekben vagy hátrányos helyzetű régiókban élőkre.

Az elmúlt években, pontosabban az elmúlt három-négy évben azonban a szemünk láttára változás következett be. Hiszen manapság csupán bizonyos régiókban és szakmákban van kevés munkalehetőség és egyre inkább az kezd jellemzővé válni, hogy hiány van a munkaerőből és nehéz megtalálni a megfelelő munkaerőt az üres pozíciókra (Mádi, 2018).

A munkaerőhiány és a munkaerő megtartása a mai modern gazdaság egyik legnagyobb problémája (Kovács,2012). Egyre nagyobb területeken foglalkoznak ezzel a problémával és a vállalatokat komoly kihívások elé állítja, vagyis a vállalaton belül a vezetőket, illetve a vállalatok humán erőforrás menedzsereit, szakembereit. Munkaerőhiány esetén a vállalatoknak emelniük kell a béreket, mivel a munkaerőpiacon fokozódik a verseny a szakképzett munkaerő megszerzéséért. Egyre gyakrabban előfordul viszont, hogy hiányzik a munkaképes lakosság, amelynek hiánya kritikus munkaerőhiányhoz vezethet. Az ilyen esetekben a vállalatok számára az egyik ilyen jövőbeni megoldást a robotizáció jelentheti. A bekövetkezendő technológiai változások hatására az automatizálható szakmák esetében a munkahelyek száma és a képzetlen munkaerő iránt a kereslet egyre inkább csökken, viszont ezzel a folyamattal párhuzamosan a magasan képzett munkaerő iránti kereslet növekedésére kell számítani (Harari,2018).

A munkaerőhiány és a fluktuáció tehát jelen van és nagy problémát okoz a vállalatoknak és a szervezeteknek és ez a modernkori probléma nem kerüli el természetesen a közszférát sem, mivel a közszférán belül is egyre nagyobb mértékben váltanak az alkalmazottak munkahelyet, nem elégedettek és ebből kifolyólag a szervezetek egyre nehezebben találnak a megüresedő posztokra, kulcspozíciókra szakképzett munkaerőt.

Több ezer betöltetlen álláshely van most is. Kazánkezelőt, rendszergazdát, óvópedagógust, mentőst és tudományos munkatársakat is keresnek közalkalmazotti helyekre. A szakszervezet szerint mégis 160 ezer olyan ember dolgozik a szférában, akinek a bére 10 éve nem változott (Hír TV, 2018). 


\section{Elméleti háttér}

Először is mi az a munkaerőpiac? A munkaerőpiac az, ahol a munkaerő-kereslet és kínálat találkozik és a kettő közötti különbség a munkaerőhiány vagy a munkaerő-felesleg (munkanélküliség).

Egy holland kutatás eredményei azt mutatják, hogy a női alkalmazottak fluktuációja leginkább összefüggésbe hozható belső tényezőkkel, míg a férfiak döntései, hogy elhagyják a közszférát, leginkább külső (extrinsic) tényezők motiválják. Az etnikai kisebbséghez tartozó férfiak esetében a szervezet irányítása és a felügyeleti vezetési stílus fontos meghatározó tényezője az állami szektor elhagyására irányuló szándéknak. A sokféleség kezelésének csak csekély negatív hatása van a munkahely elhagyásra vonatkozó szándéknak (Sandra, 2011).

A bérek emelkednek, a háztartások jobban boldogulnak, de Európában és Szlovákiában is a vállalkozások panaszkodnak és egyre negatívabbak, hiszen már hiányzik a képzett munkaerő és a felmerülő pozíciókba nem tudnak megfelelő tudással rendelkező alkalmazottat találni a munkaerőpiacon. Nemcsak a politikai vezetők, hanem számos európai felmérés is alátámasztja a vállalatok aggodalmait és borúsan látják a helyzetet a jövőre nézve, ha nem következnek be a szükséges változások. És miközben a vállalatok keresnek, a tehetséges emberek eltűnnek, inkább külföldön vállalnak munkát nagyobb bérért és magasabb életszínvonal mellett. Minden azt sugallja, hogy a munkaerő-piaci fejlemények az elmúlt években pozitív irányba haladtak a környező országokban. A közép-európai régióban lévő vállalatok azonban másképp látják a helyzetet (Žuffa, 2017).

Magyarországon a munkaerőhiány az elmúlt évek tendenciájához hasonlóan tovább növekedett. Szélesedett azon munkakör kategóriák száma, ahol egyre hosszabb időt kíván a megfelelő munkaerő megtalálása és az üres, betöltetlen pozíció betöltése (Sebők, 2017).

Egyre növekszik a munkavállalók külföldre való kiáramlása és ezzel párhuzamosan a külföldi munkavállalási kedv. A rendszerváltó országok csatlakozásával a tagországok közötti migráció új lendületet vett és ennek hatására a korábbitól eltérő folyamatokat generált. Ennek az új típusú vándorlásnak az elsődleges célja a munkavállalás. A statisztikai adatok alapján a magyar állampolgárok kivándorlás mértékének erősödése 2008-ban kezdődött, jelentősebb megerősödése 2010-től mutatható ki (Sebők, 2017). Egyes források (BBJ, 2018) szerint ez az érték napjainkra elérte a több mint 340 ezres számot.

A képzési struktúrák mindig nagyon messze vannak attól, hogy összhangban legyenek a vállalkozói érdekekkel és ennek tükrében szakadék jön létre a két fél között. Az egyes szektorokban tapasztalható mennyiségi és minőségi munkaerőhiány két fő tényezőre vezethető vissza. Az egyik az ún. „skill gap”, amikor a munkaképes korú felnőttek nem rendelkeznek a megfelelő készségekkel, sokszor a szükséges alapkompetenciákkal sem. A másik az ún. „skill mismatch”, amikor a gazdaság humánerőforrás igényének szerkezete nem egyezik meg a felnőttek képzettségi struktúrájával, tehát a képzésen szerzett tudás nem egyezik meg azzal, amit a vállalaton belül elvárnak és megkövetelnek. Ez úgy kezelhető és csökkenthető, ha már az alapok oktatásánál próbál azonosulni a két érdek és az alapkompetenciák szerint felkészíteni az egyéneket (Sebők, 2017).

Nagy problémát jelent maga a fluktuáció jelenléte a vállalatok és intézmények életében. A fluktuáció számít a humán erőforrások egyik fontos teljesítményindexének. A fluktuáció emelkedése olyan történésekre, problémákra és hibákra következtet, amelyek egy szervezet jövőbeni sikeres és effektív működését merőben gátolják. A fluktuáció kezelésére, ezért a gyakorlatban azonnali lépéseket és alkalmazható módszereket szükséges eszközölni (Boudreau,2010). 
A fluktuáció magas szintje gyakran jelentős költségeket ró a szervezetekre. A fluktuációhoz kapcsolódó költségek az üres álláshelyek, a képzésre fordított erőforrások, és talán a legfontosabb, az emberi tőke elvesztésének költségei mind-mind a szervezetnek komoly költségekkel jár (Grissom-Grotty-Keiser, 2016).

A fluktuáció problémakörre és csökkentésére megoldásnak tűnhet egy a gazdaság javítása. Mivel a munkanélküliségi ráta csökkenő tendenciát mutat, a magánszektornak lehetősége van arra, hogy a meglévő munkaerőt a vállalatok magukhoz láncolják és számukra dolgozhatnak. A közszektor számos okból különösen sérülékeny, nem utolsósorban azért, mert sok ország nem tud lépést tartani a magánszektorral a fizetés szempontjából. A morális kérdés is fontos tényező. Egyre inkább csökkennek a kedvezmények, mint például a nyugdíjalapok és az egészségügyi ellátás. A vállalaton belül létező dolog, hogy egy alkalmazott egyszerre két munkát végez, két pozíciót tölt be és már ott tartunk, hogy a munkavállalói morál rosszabb, mint a recesszió előtt (Barrett-Greene, 2014).

Szóval, mit a teendő a fluktuáció csökkentése érdekében? A fizetés emelése nyilvánvaló válasznak túnik, de sok esetben nem praktikus. Vannak azonban más útvonalak a fluktuáció csökkentésére, beleértve a következőket:

- Megérteni, hogy miért hagyják el az emberek munkájukat - kilépés előtti beszélgetések, az okok feltárása és a szükséges következtetések a jövőre nézve - mélyreható vizsgálat

- Az elavult fizetési struktúrák frissítése- versenyképes fizetési rendszer

- Dolgozni az egyéni munkahelyek megértésén és az alkalmazottak előtt álló akadályok megértésén - felállítani egy olyan felügyeletet, aki figyeli, hogy az alkalmazottak ne terheljék túl magukat (Barrett-Greene, 2014).

Figyelembe véve a szervezetek egyre növekvő igényeit, azaz, hogy a versenytársakkal szemben megtartsák a legjobb munkavállalókat, a tanulmány megállapításai arra utalnak, hogy bizonyos változók döntő szerepet játszanak abban, hogy befolyásolják a munkavállalók döntését akkor, amikor arról döntenek, hogy elhagyják vagy maradjanak egy szervezetben. Az ilyen változók közé tartozik a képzés és fejlesztés, a jó teljesítmény elismerése/jutalma, a versenyképes fizetési csomag és a munkahelyi biztonság. Mindazonáltal az egyéb változók fontosságát nem szabad alábecsülni a megtartási, meggyőzési politika megfogalmazásakor. Egy átfogó keveréke a belső és külső motivációs változóknak, amelyek növelhetik a megtartást és csökkenthetik a különböző szervezetekben a munkavállalók magas forgalmát (Samuel-Chipunza, 2009).

A közszféra egésze igen heterogén, idetartoznak a kormánytisztviselők, köztisztviselők, közalkalmazottak, hivatásos szolgálati jogviszonyban foglalkoztatottak, a munkatörvénykönyv alapján foglalkoztatott, de közszolgálati feladatot ellátó személyek, továbbá az állami vállalati szektorban dolgozók. Az elmúlt években a közszférát érintő szabályozási változások, az elhúzódó gazdasági válság és mostanában a piac egyre nagyobb stabilitása mind olyan tényezőknek bizonyulhatnak, amelyek alkalmasak arra, hogy megváltoztassák a munkaerő-áramlás jellegzetességeit, mintázatait, mennyiségi sajátosságait (Gellén, 2013).

Az alkalmazottak fluktuációja kulcsfontosságú terület a közigazgatás kutatásában, de még mindig olyan területnek számít, amelyről sok mindent meg kell még tanulni (Grissom et al.,2016).

Az általános üzleti probléma, hogy a közintézmények költségeket és fontos ismereteket és tudást veszítenek el, valamint tapasztalt munkavállalókat a munkavállalói fluktuáció miatt. A konkrét problémát az okozza, hogy az egyes állami szektor vezetőinek nincsenek stratégiái a munkavállalók megtartásának javítására (Carroll-Izard, 2016). 
Hatalmas a munkaerőhiány a közszférában, több ezer betöltetlen álláshely van most is. Kazánkezelőt, rendszergazdát, óvópedagógust, mentőst és tudományos munkatársakat is keresnek közalkalmazotti helyekre. A szakszervezet szerint mégis 160 ezer olyan ember dolgozik a szférában, akinek a bére 10 éve nem változott. Van olyan közalkalmazott, akinek a bére több évtizedes munkaviszony után sem éri el a pályakezdő szakmunkás bérét (HRPortal, 2018).

A közszféra dolgozói közfeladatok ellátását végzik, munkáltatóik költségvetésből múködő szervezetek A közszektor, amely a munkaerőpiac keresleti oldalán álló szereplőként jellemezhető, és aki az összes többi munkaadóval versenyben áll a jó szakemberek megszerzéséért, megtartásáért. Az automatizálható, robotizálható megoldásokkal kiváltható szellemi munkát végzők iránt csökkenni, míg a szociális empátiával, kreativitással, vezetői, elemzői képességekkel rendelkező munkatársak iránt nőni fog a kereslet. Tehát a jelenleginél kevesebb, de más tudással és készségekkel rendelkező munkaerőre lesz szükség a jövőben és ez a jelenség a közszolgálat számos területére is nagy hatással lesz (Domokos-Jakovác-Németh, 2016).

A hazai közszféra hatalmas munkaerőpiac kihívások elé néz és ez csak fokozódni fog a jövőben. Magyarországon a közszférában dolgozók aránya nemzetközi összehasonlításban az átlagnál magasabb; a 4,5 millió főt elérő, gazdaságilag aktív népesség 19 százalékát teszi ki, a KSH adatai szerint minden ötödik munkavállaló a közszférában dolgozik, amely csaknem 860 ezer főt jelent (Linder, 2014).

A közszférában dolgozó alkalmazottak rendkívül fontos szerepet töltenek be, mind méretben, mind a feladatellátás tekintetében. Mindenki érdekéül szolgál, hogy a közszféra dolgozói feladataikat jó minőségben, hatékonyan lássák el. Ez a folyamat viszont, csak úgy érhető el, ha a közszférába kerülők magas szintû tudással és jó képességekkel rendelkeznek és hosszabb távon az adott helyen maradnak is. De a legtöbb szakember véleménye szerint, valamint az ehhez kapcsolódó kutatások azt mutatják, hogy bár a közszférában sokan dolgoznak, a jó munkaerő megszerzése, megtartása egyre nehezebbé válik. Így munkaerő-többlet és munkaerő-hiány egyaránt jelen van.

A közszféra, mint a kereslet oldal szereplője a piacon a magánszektorral, a külföldi munkaadókkal kell versenyeznie a megfelelő munkaerőért. Azonban az üzleti szféra magasabb béreket és presztízst kínál, miközben a közszférát az alacsony jövedelem, a (relatív) lapos bérpálya, a jellemzően nem teljesítményalapú bérezés, illetve a jövedelem-differenciálás szűk tere jellemzi. Ezen felül a közszférában további okok merülnek fel, amelyek elégedetlenséghez vezetnek, ezek az okok a korábbi komparatív előnyök (stabilitás, kevesebb munkaidő) mérséklődése, a közszolgálat alacsonyabb presztízse, a karriertervezés problémái, az elsősorban nem teljesítményalapú előmeneteli rendszer, a túlbürokratizált folyamatok, illetve az (információ) technológiai lemaradás (Domokos-JakovácNémeth, 2016).

A közszférától való távolmaradás, illetve a közszolgálatból való kilépés legfontosabb, és egyben leggyakrabban említett oka az alacsony jövedelem. A jövedelem után gyakori oknak minősül a jelenlévő bürokrácia és tehetetlenség az alkalmazottak részéről. Gondolunk itt arra, hogy egyes intézkedéseket bonyolultak és feleslegesek, lehetetlen előrelépni és fejlődni. Minden innovatív ötletnek az állam az útját állja. A következő ok szintén ide köthető, azaz a túlzott politikai befolyás, a pozíciókat azért kapjak meg egyesek, mivel befolyásos kapcsolatokkal rendelkeznek és nem a tudásuk vagy a tapasztalatuk miatt. A távolmaradás és a gyors kilépés oka a tisztelet hiányából is fakad és a rossz, alkalmatlan vezetők, igazgatók és menedzserek személye miatt (Barrett-Greene, 2007).

Az elérhető jövedelmen kívül azonban több más és fontos tényező is hozzájárul a jó munkaerő megszerző és megtartó képességhez. Ilyen lehet például maga a munka presztízse, a szakmai megbecsültség, a karrierlehetőségek, a továbbképzési lehetőségek (munkaidő részeként), a 
munkahely stabilitása, a rugalmas munkabeosztás lehetősége, a több szabadidő és a megfelelő munkakörülmények megléte. A Select International konzultációs szakértője, Thomas (2017) szerint a vállalatoknak az alábbi öt szempontot kell figyelembe venniük, ha meg akarják tartani a tehetséges munkavállalóikat:

- Megfelelő munkavállalói környezet, munkahelybiztonság kialakítása.

- Egyértelmúen tisztázott célok és elvárások, amelyben kulcsfontosságú szerepe van a szervezeti kommunikációnak és munkaköri leírásoknak.

- Nyílt munkakörnyezet, amiben szerepet játszanak a rendszeres visszacsatolások.

- Képzés-fejlesztés támogatása, kihívást és ösztönzést jelentő munkafeladatok.

- A jó munka elismerése, megbecsülése és jutalmazása (Thomas, 2017).

A pénzbeli és nem pénzügyi juttatások szintje jelentős hatással van arra, hogy hány munkavállalót foglalkoztat egy közszféra szervezete, és hány munkavállaló lesz hajlandó a felkínált pozíciókat elfogadni és ott maradni a szervezetben (McGuire, 2015).

A munkavállalói termelékenység és a forgalom közötti kapcsolat a politika és a menedzsment szempontjából lényeges, mert részben meghatározza, hogy a forgalom csökkentésére irányuló hatások hosszú távon valószínúleg hatékonyabb szervezetet eredményeznek (Grissom et al., 2016). A munkaerőhiány okainak megközelítése során több okot is megfogalmazhatunk. Ezek az okok a következők:

- a jelenlegi demográfiai folyamatok következtében csökken a gazdaságilag aktív, a munkaerőpiac kínálati oldalán megjelenő munkavállalók száma,

- továbbra is magas a munkaképes lakosság körében a gazdaságilag nem aktívak száma,

- a külföldön munkát vállalók száma 2010 óta folyamatos növekszik,

- az oktatási rendszerből fakadó problémák (pl. alap- és digitális kompetenciák vagy a szakképzési hiányosságok) következtében,

- a munkanélküliek és a közmunkások között is magas az alacsony iskolai végzettségúek aránya,

- a magyar bérek alacsony színvonala és versenyhátránya már a szomszédos országokkal szemben is (Bagó, 2018).

A munkaerőpiac állandóan és gyorsan változik. Olyan világban élünk, ahol minden piacon óriási verseny folyik: az áruk, szolgáltatások piacán a vevőkért, a tőkepiacon a befektetőkért, a munkaerőpiacon a legjobb munkaerőért. A munkáról és az ideális munkaadóról alkotott kép is gyorsan változik, a globalizáció, az innováció, az automatizáció térnyerése gyökeresen megváltoztatja a munkaerőpiac keresleti és kínálati oldalát egyaránt (Domokos-Jakovác-Németh, 2016).

A munkaerőhiányt tehát orvosolni kell, melynek során különböző stratégiákat választhat a vezető, amennyiben a munkáltatási körülmények és jogi, pénzügyi, szabályozási feltételek megfelelő teret biztosítanak.

A munkaerő hiánya 2019-ben is az egyik fő téma lesz. Ebben az évben a munkaerőpiac fokozatosan fellélegezhet. A gazdasági növekedés várható lassulása fokozatosan csökkenteni fogja a munkaadók munkaerő-igényeit (TASR, 2019).

Ha 2018-as év arról szólt, hogy kik kapnak munkát, a 2019-es év fő kérdése az lehet, hogy a munkahelyi munka hogyan is múködik. Valójában ez lehet az az év, amikor a szervezetek megkezdik megtervezni az újrakezdés alapjait, megújulnak, hogyan találják meg, értékeljek és fizessék (Macdonald, 2018). 
A Korn Ferry tehetségszerző szakembereket, kompenzációs szakértőket és HR szakembereket kérdezett meg és dolgozott velük össze a világ minden tájáról, hogy 2019-ben 10 új tehetség trendet azonosítsanak, amely elöre lendítheti a munkahelyeket, azaz hatékony munka mellett elégedett alkalmazottak (Macdonald, 2018). A 10 új trend a következő:

- A mesterséges intelligenciát még inkább intellingessé fejleszteni: A mesterséges intelligenciát (AI) a toborzás új szent gráljává tették. A szakértők azonban attól tartanak, hogy az „intelligencia” nem összpontosít majd a sokféleségre és a befogadásra. Az Al gyakran a rendelkezésre álló tényezőkből képes a jelentkező nemére következtetni. Például a „vételért felelős” és a „kemény feladatok” gyakran a férfiakhoz kapcsolódik, míg a „meggyőzés” és a „megértés elkötelezettségét” a nők gyakran használják és hozzájuk csatolja. Az Al-t arra is ki kell képezni, hogy jobban megismerje az adott szerephez szükséges készségeket ahelyett, hogy a szubjektív módosítókra összpontosítana - az egyik ilyen mód lehet, hogy a részleges adatok helyett bővebb és szerteágazóbb adatokat táplálunk a rendszerbe

- Ne felejtsünk: Előfordul olyan időszak, hogy az adott jelentkező képességei éppen nem aktuálisak, nem múködőképes a kapcsolat. Az ilyen jelentkezőket észben tartani és a jövőben gondolni rájuk. Sok cég kezdi el keresni az ilyen elfeledett embereket és ennek érdekében múhelyeket, testreszabott céloldalakat, valamint más eszközöket használnak az emberek megtalálásához.

- Személyre szabott fizetés: menj elöre, mi meghallgatunk: Jelenleg négy generáció van a munkaerőpiacon, amelyek mindegyike eltérő elvárásokkal rendelkezik a fizetési és jutalomcsomagok tekintetében. Az előre gondolkodó cégek társasági beszélgetéseket, fókuszcsoportokat és felméréseket használnak arra, hogy kitalálják, hogy mit is akarnak az egyes generáción belül. Ezzel az információval képesek a jutalomcsomagokat személyre szabni, különféle fizetési, időszakos, fizetett szabadidő, nemzetközi megbízások, hallgatói kölcsön visszafizetés és egyéb előnyök kínálatával.

- Az éves teljesítmény felülvizsgálatának átgondolása: A szakemberek a felmérések alapján azt vallják, hogy az éves felülvizsgálás nem befolyásolja a vállalat múködését, nincs kellően hatással rá és jobb lenne erre kiegészítőként tekinteni, mivel a valós idejú visszajelzés sokkal hatékonyabban múködik. A folyamatos visszajelzés segítheti a munkavállalókat a tanulásban és a munkaképességeik fejlesztésében.

- Mélyebbre ásni a sokféleség és a befogadó csővezetékébe: A világ minden táján egyre több nőnek van az igazgatósági és egyéb vezetői pozíciókban munkája. Míg ez egy jó kilátás, a vállalatoknak a szervezet minden szintjére kell összpontosítaniuk, hogy létrejöjjön a változatosság a tehetségek folyamatos csővezetékén keresztül, köztük a nők, a színes emberek, a fogyatékkal élők és az LGBTQ alkalmazottai egyaránt összhangban és megértésben.

- Hogyan csináljuk? Hogyan érezzük?: A fogyasztói termékeket árusítók és a kiskereskedők évek óta felmérik az ügyfeleket a márkával kapcsolatos tapasztalataikról. Ez a gyakorlat egyre inkább része a toborzási folyamatnak. A technológia lehetővé teszi a jelentkezők valós idejü visszajelzéseit a felvételi ciklus során szerzett tapasztalataikról. A felmérési eszközök visszajelzést keresnek a folyamat minden pontján, ami a toborzóknak és a vezetők adatvezérelt betekintéseinek és intelligenciájának felvételére szolgál. Az adatok segítségével módosíthatják a toborzási gyakorlatokat, beleértve a konkrét munkahelyi követelményeket és a jelöltekkel való kölcsönhatásokat, hogy sikeresen múködjön a felvételi rendszer és a legjobb embereket vegyék fel. 
- Ez valóban egy létező pozició? : Az adathordozóként funkcionáló vezérigazgató. Úgy tűnhetnek ezek a posztok, mint valami falon kívüli munkakörök, de az ilyen szerepek számos iparágban jelentkeznek, hogy megfeleljenek a szervezetek változó stratégiáinak. Néhány érv ugyancsak felbukkan a fiatalabb munkavállalók vonzására. Például az adatgyűjtők felelősek az adatok halmozásának megszervezéséért és értelmezéséért és ezek az ún. jogi ninják és a hozzájuk társuló jogi segédanyagok számítanak az új generációjának. Az egészségügyben és a pénzügyekkel foglalkozó cégek arra törekesznek, hogy olyan vezetőt nevezzenek ki, akinek nagy tapasztalata van az adott területen.

- A tehetség elemzés ugyanolyan fontos, mint az üzleti elemzés: Az üzleti vezetők hagyományosan az üzleti elemzések elemzésével határozzák meg stratégiájukat, hogy meghatározzák a költségeket és a múködési hatékonyságot. A szakértők azonban azt mondják, hogy kudarcot vallanak, mert nem találják meg a megfelelő típusú tehetségeket. A cégek egyre inkább a tehetségek elemzését veszik be a keverékbe. Ezek az adatok olyan dolgokat mérnek, mint például a régió minősített tehetségének versenye és a kompenzációs normák összefüggései.

- Beszélgetés és a tehetségek megértése - a munkakezdéstöl a nyugdijba vonulásig: Az adatok hatalmas beáramlásával feltételezhető, hogy a szervezetek integrált módokat használnak a tehetségdöntések összes elemének elemzésére, beleértve a toborzást, a kompenzációt és a fejlesztést. Sajnos sok szervezetben ezek a funkciók különböző „nyelveken” múködnek, gyakran nem tudnak egymással beszélni, kommunikálni

A szakértők azt mondják, hogy van egy tendencia egy alaposabb, adatközpontú megközelítés irányába, amely betekintést nyújt a szervezeti, csapat és egyéni perspektívákból. Ez lehetővé teszi a tehetségek kalibrált megközelítését, amely szorosan kapcsolódik az üzleti eredményekhez. Például a felvételi folyamat során gyűjtött adatok felhasználhatók arra, hogy a jelölt felvételekor hozzanak létre egy személyre szabott fejlesztési programot.

- A rövid távú alkalmazotti igények kezelése hosszú távú üzleti célokkal: A technológiai fejlődés sebessége és a változó üzleti prioritások megismerése elősegíti annak megértését, hogy mi fog történni a következő évben - vagy akár a jövő hónapba. Valójában egy közelmúltbeli Korn Ferry által készített felmérésben a tehetséggazdálkodási szakemberek 77\% azt mondja, hogy ma már olyan szerepeket vesz fel, amelyek nem is léteztek egy évvel ezelőtt. A vezető szervezetek holisztikus megközelítést alkalmaznak a tehetségszerzésben. Rövid távon felgyorsítják a bérbeadást. Ugyanakkor egy hosszabb távú megközelítésre összpontosítanak azzal, hogy mélyen merülnek be az üzleti szükségletekbe, hogy egy olyan teljes stratégiai tervet hozzanak létre, amely egyértelműen meghatározott célokat tartalmaz, de szükség szerint módosítható (Macdonald, 2018).

\section{Empirikus vizsgálat}

\section{Minta}

A Szent István Egyetem Menedzsment és HR Kutató Központja és a Nemzeti Közszolgálati Egyetem Államtudományi és Közigazgatási Kar Emberi Erőforrás Intézete kutatóinak a TESK Csoport támogatásával, valamint a Budapesti Kereskedelmi és Iparkamara, a Humán Szakemberek Országos Szövetsége (HSZOSZ), és a Országos Humánmenedzsment Egyesület (OHE) szakmai közremúködésével 
elkészített felmérés alapján mutatjuk be a tanulmányunkban a fluktuáció és a munkaerőhiány közszférában tapasztalható leglényegesebb kérdéseit.

A szerzők által végzett vizsgálatok adatait 2017-ben gyújtötték össze. A mostani írásban a kutatók azt elemzik, hogy a közszférában múködő magyarországi szervezetek esetében miképpen alakul a munkaerőhiány kérdése a felsőfokú végzettségűek esetében. A kutatásban a mintagyújtés módszere a hólabda módszer volt ezért a minta nem tekinthető reprezentatívnak.

A kutatásban a kérdőív alapvetően zárt jellegú kérdésekből állt, így nominális és metrikus skálákból. A lekérdezés interneten keresztül valósult meg, a kutatás emiatt sem tekinthető reprezentatívnak. A kiértékelési módszerek egy- és többváltozós vizsgálati eljárások voltak: gyakorisági vizsgálatok, átlag-és szórásértékelések, kereszttábla-elemzés, ANOVA, faktor- és klaszterelemzések.

Összesen 2194 magyarországi közszférabeli szervezet vett részt a felmérésben. A résztvevők létszám és a költségvetési jellemzőjét az 1. táblázat mutatja be:

1. táblázat: A résztvevő szervezetek létszám és költségvetési jellemzője (\%)

\begin{tabular}{|c|c|c|c|}
\hline Létszám & $\%$ & Éves költségvetés & $\%$ \\
\hline $2-9$ fö között & 1,7 & 10 millió Ft alatt & 21,6 \\
\hline $10-50$ fö között & 19,1 & $10-100$ millió Ft között & 22,0 \\
\hline $51-100$ fő között & 11,6 & 100 millió-1 mrd Ft között & 17,9 \\
\hline $101-250$ fö között & 6,7 & $1-10$ mrd Ft között & 15,7 \\
\hline $251-500$ fö között & 6,1 & $10-100$ mrd Ft között & 12,3 \\
\hline $501-1000$ fö között & 10,3 & 100 mrd Ft felett & 10,4 \\
\hline 1000 fó felett & 44,4 & & 100,0 \\
\hline Total & 100,0 & & \\
\hline
\end{tabular}

Forrás: A szerzők saját szerkesztése

A táblázat adataiból megállapítható, hogy a minta több mint fele a nagyméretű szervezetekből került ki, és az intézmények közel 40\%-a 1 milliárdnál nagyobb költségvetéssel rendelkezett.

A szerzők a következő hipotézis vizsgálatát végzik el a tanulmányban:

\section{Hipotézis}

Az előző elemzéseinkből egyértelmúen kitűnik, hogy a közszféra elhagyásának egyik leggyakoribb oka az alacsonyjövedelem. Ebből kifolyólag a kutatásunk fő hipotézisének alapjául ezt a tényt választottuk.

A kutatásban részvevő közszférában müködő szervezetek esetében a felsőfokú végzettségüek fluktuációjának alapvető magyarázata a javadalmazás. .A tanulmány további része a fenti állítás elemzését mutatja be: 


\section{Elemzés}

A kutatásban szereplő szervezetek elmondása szerint 2016-ban a fluktuáció mértéke 0\% volt a válaszolók 5\%-nál. Ugyanakkor mintegy 50\%-uknál 5\%-20\%-os nagyságú volt az alkalmazottak számának ingadozása, míg 53 szervezet arról nyilatkozott, hogy $40 \%$ feletti a fluktuáció nagysága.

A kutatók tovább szúkítették az ingadozásra vonatkozók körét, így rákérdeztek arra, hogy milyen mértékű volt a felsőfokú végzettségűek körében a dolgozói szám alakulása. 65 szervezet e csoportra vonatkozóan megjegyezte, hogy $40 \%$ feletti volt az ingadozás, míg 40\%-uk 5\%-20\% mértékűről nyilatkozott.

Összevették a szerzők, hogy van-e összefüggés a létszám, a szervezetek költségvetése és a fluktuáció mértéke között. A Khi-négyzet próba szignifikáns kapcsolatot mutatott a szervezeti fluktuáció nagysága és a szervezeteknél foglalkoztatottak létszáma között (Pearson-féle Khi-négyzet: 87,825 df: 30 szign.: ,000 p<0,05): Vagyis a nagy létszámmal dolgozó szervezeteknél a fluktuáció nagysága jellemzőbben kisebb volt, mint az apróbb méretűek esetében. Míg például a nagyszervezetek tekintetében 1,8\%-uknál nincs elvándorlás, addig ennek a mértéke a 10-50 fővel dolgozó szervezeteknél már közel 11,4\%. A 40\%-nál nagyobb nagyságú fluktuáció leginkább a 251-500 főt foglalkoztató szervezeteknél volt jellemző (6,7\%):

A felsőfokú végzettségúek fluktuációja és a szervezeti méret között szintén volt szignifikáns kapcsolat (Pearson-féle Khi-négyzet: 95,195 df: 30 szign.: ,000p<0,05): A felsőfokú végzettségű munkavállalók kevésbé hagyják ott a nagyméretû szervezeteket, mint a kisebbeket.

A szervezetek költségvetése és a fluktuáció mértéke között nem volt igazolható a szignifikáns összefüggés.

Felvetődött a kérdés, hogy mi az oka annak, hogy a szervezeteknél a munkavállalói hiány kialakul. A kutatók a vizsgálat során rákérdeztek erre is. Miután jelen tanulmány kimondottan a felsőfokú végzettségűeket vizsgálja, az írás kimondottan erre a munkavállalói csoportra vonatkozó eredményeket tárgyalja.

Egy ötös skálán kellett a válaszadóknak értékelniük, hogy milyen okai lehetnek annak, hogy kevesebb a felsőfokú végzettségű munkavállaló, mint amennyit a közszférában múködő szervezeteknél igényelnének. Az egyes az ok teljes elutasítását, míg az ötös érték a teljes elfogadását jelentette. A 2. táblázat a válaszok alapján meghatározható átlagokat és szórásokat mutatja be. 
2. táblázat: A felsőfokú végzettségűek hiányának okai a közszférában (átlag, szórás)

\begin{tabular}{|c|c|c|c|c|}
\hline \multirow[b]{2}{*}{ Okok } & \multicolumn{2}{|c|}{$\mathbf{N}$} & \multirow[b]{2}{*}{ Átlag } & \multirow[b]{2}{*}{ Szórás } \\
\hline & Érvényes & Hiányzó & & \\
\hline A versenytársak konkurenciája & 1220 & 974 & 3,42 & 1,461 \\
\hline A túl alacsony bérek & 1382 & 812 & 3,82 & 1,284 \\
\hline A szakképzett munkaerő hiánya & 1284 & 910 & 3,33 & 1,388 \\
\hline A külföldi elvándorlás & 1208 & 986 & 2,46 & 1,443 \\
\hline $\begin{array}{l}\text { A gazdasági növekedés miatt kevesebb } \\
\text { munkanélküli }\end{array}$ & 1101 & 1093 & 2,17 & 1,248 \\
\hline $\begin{array}{l}\text { A csökkenő népesség miatt kevesebb } \\
\text { munkaképes személy }\end{array}$ & 1161 & 1033 & 2,17 & 1,238 \\
\hline Az oktatási rendszer problémái & 1213 & 981 & 2,68 & 1,385 \\
\hline A rossz munkakörülmények & 1273 & 921 & 2,46 & 1,376 \\
\hline A közlekedési infrastruktúra hiányosságai & 1234 & 960 & 1,95 & 1,175 \\
\hline $\begin{array}{l}\text { A munka és magánélet összehangolásának } \\
\text { nehézségei }\end{array}$ & 1251 & 943 & 2,56 & 1,347 \\
\hline
\end{tabular}

Forrás: A szerzők saját szerkesztése

Megállapítható, hogy legfontosabb indok a financiális magyarázat, ami miatt felsőfokú tanulmányokkal rendelkezők nem választják a közszférát. A másik igen jellemző ok, hogy máshonnan jobb ajánlatokat kapnak ezek az alkalmazottak. Ugyanakkor jó hír, hogy elhanyagolható indokként azonosítható volt, a közlekedési infrastruktúra hiányosságai. Kevésbé fontos szempontként jelentkezett, még az oktatási rendszer problémája, avagy a munkanélküliek számának alakulása, igaz igen magas átlagot kapott a közszférában megmutatkozó szakemberhiány. Tény azonban, hogy minden indok esetében a szórás igen magas értéket mutatott, ami azt támasztja alá, hogy a válaszadók nem voltak egyöntetú véleményen az indokokat illetően. Továbbá az eredmények értékelésénél nem szabad figyelmen kívül hagyni, hogy sok megkérdezett nem adott választ az adott kérdésre.

A további elemzések céljából a szerzők az indokokat faktorokba tömörítették. Nem minden változó volt alkalmas a faktorképzésre. A KMO érték: 0,784, a Bartlett teszt: a hozzávet. Khi-négyzet: 1869,8 df: 36 szign.: 0,00. A faktorok rotálása ortogonális forgatási módszerrel, és azon belül is Varimax-eljárással történt. A faktorok magyarázott varianciahányada $62,511 \%$ lett, amely elfogadhatónak tekinthető. A faktorsúlyok alapján a faktorok a következőképpen azonosíthatóak: 
3. táblázat: Rotált komponens mátrix

\begin{tabular}{|l|c|c|c|}
\hline \multicolumn{1}{|c|}{ Változók } & \multicolumn{2}{c|}{ Faktorok } \\
\cline { 2 - 4 } & $\mathbf{1}$ & $\mathbf{2}$ & $\mathbf{3}$ \\
\hline A rossz munkakörülmények & 0,791 & & \\
\hline A munka és magánélet összehangolásának nehézségei & 0,778 & & \\
\hline A közlekedési infrastruktúra hiányosságai & 0,765 & & \\
\hline Az oktatási rendszer problémái & 0,548 & & \\
\hline A túl alacsony bérek & & 0,792 & \\
\hline A versenytársak konkurenciája & & 0,757 & \\
\hline A szakképzett munkaerő hiánya & & 0,599 & \\
\hline A gazdasági növekedés miatt kevesebb munkanélküli & & & 0,846 \\
\hline A csökkenő népesség miatt kevesebb munkaképes személy & & & 0,813 \\
\hline
\end{tabular}

Forrás: A szerzők saját szerkesztése

A választott faktorok:

1. faktor: Munkahely kínálta objektív lehetőségek.

2. faktor: Financiális indok és a konkurencia kínálta lehetőség.

3. faktor: A munkaerőszám potenciális csökkenése a munkaerőpiacon.

A faktorok segítségével klasztereket hoztunk létre. Arra voltunk kíváncsiak, hogy milyen homogén csoportok alkothatók ezeknek a faktoroknak a segítségével. A K-közép eljárással 3 klaszter kialakítására került sor. A klaszterek a következő elnevezéseket kapták:

1. klaszter: Azok a válaszadók kerültek ebbe a csoportba, amelyek szervezeteinél a potenciális munkaerőlétszám csökkenése és a szervezet szerény infrastruktúrája okozza a munkaerőhiányt.

2. klaszter: Ezeknél a szervezeteknél alapvetően a bér az alapvető indok, hogy nem választják a felsőfokú végzettségúek az itt adódó munkát.

3. klaszter: Ezeknél a szervezeteknél viszonylag kedvezőek a lehetőségek a felsőfokú végzettségűek számára, különösen az infrastruktúrát illetően.

A válaszadó szervezetek közül 360-an az első klaszterben, a 282-en a második klaszterben, míg 293-an a harmadik klaszterben foglaltak helyet.

Megvizsgálásra került, hogy a klaszterbe sorolás és aközött, hogy milyen az adott szervezet létszáma és költségvetése lehet-e bármilyen szignifikáns kapcsolatot találni. Ennek megválaszolására a szerzők Khinégyzet próbát végeztek a klaszterek és a létszám, illetve a költségvetési változók között. Az eredmények azt mutatták, hogy egyik változó esetében sem volt igazolható a szignifikáns kapcsolat (a létszám alapján: Khi-négyzet próba: Pearson-féle Khi-négyzet: 12,471 df: 12 szign.: ,409 p>0,05, az árbevétel szerint Khi-négyzet próba: Pearson-féle Khi-négyzet: 8,831 df: 10 szign.: ,548 p>0,05). 
A szervezetek, a létszám alapján történő elemzésekor, leginkább az első klaszterben foglaltak helyet, legnagyobb arányban a mikro (53,8\%-uk), a 101-250 fóvel múködő szervezetek (51,4\%-uk), míg legkisebben az 51-100 föt foglalkoztató szervezetek (34,2\%-uk). A legnagyobb arányban a kedvező lehetőséget nyújtó szervezetek (azaz a 3. klaszterben megtalálhatóak) az 500 fônél több alkalmazottat foglalkoztató szervezetek vannak. Közülük minden harmadik ilyen típusú szervezet volt.

A költségvetési bevétel alapján az első klaszterben, a legnagyobb arányban a 100 millió-1 milliárd közötti szervezetek (47,6\%-uk), és az 1-10 milliárd közötti szervezetek voltak (46,5\%-uk). A harmadik klaszterben a 10-100 millió közötti szervezetek kerültek (37,1\%-uk).

Végezetül a kutatásban a válaszadóknak arra kellett válaszolniuk, hogy a munkaerőhiány megoldására általában, beleértve a felsőfokú végzettségúeket is, milyen megoldási eszközeik vannak. A 4 táblázat ezeket foglalja össze:

4. táblázat: A fluktuációt és a munkaerőhiányt csökkentő eszközök ( $N$,\%)

\begin{tabular}{|c|c|c|}
\hline Megoldási variációk & $\mathbf{N}$ & $\%$ \\
\hline A toborzás kiterjesztése a határokon túlra & 41 & 0,9 \\
\hline Több elemet kombináló húségprogram & 53 & 1,2 \\
\hline Életbiztosítás & 65 & 1,4 \\
\hline Egészségbiztosítási program & 90 & 2,0 \\
\hline Atipikus foglalkoztatási formák (részmunkaidő, osztott munkakör, távmunka) & 92 & 2,1 \\
\hline Nyugdíjbiztosítási program & 95 & 2,1 \\
\hline Vonzó hosszú távú ösztönzési rendszer (pl. részvényjuttatás, cash plan) & 96 & 2,1 \\
\hline Karrier és utánpótlás menedzsment program & 103 & 2,3 \\
\hline Általános kompetencia értékelési és fejlesztési program & 110 & 2,5 \\
\hline $\begin{array}{l}\text { Munkavállalói elégedettség és elkötelezettség növelő programok } \\
\text { múködtetése }\end{array}$ & 124 & 2,8 \\
\hline Extra szabadság napok biztosítása & 124 & 2,8 \\
\hline Kulcsember megtartási program & 128 & 2,9 \\
\hline Cégautó juttatás & 130 & 2,9 \\
\hline Gyakornoki program & 141 & 3,1 \\
\hline Speciális képzési program, egyéni fejlesztési terv & 148 & 3,3 \\
\hline Oktatási intézményekkel való együttmúködés (egyetem, szakképző) & 156 & 3,5 \\
\hline Rugalmas munkaidő alkalmazása & 204 & 4,5 \\
\hline Munkavégzési körülmények javítása & 269 & 6,0 \\
\hline Teljesítményértékelési és prémiumrendszer & 277 & 6,2 \\
\hline Versenyképes bérezési, fizetési rendszer & 397 & 8,9 \\
\hline
\end{tabular}

Forrás: A szerzők saját szerkesztése 
Jól látható, hogy a közszolgálat munkáltatói is tudják, hogy alapvetően a javadalmazást kell megoldani, amely a hiány leginkább kiváltó oka. Ezt kiegészítve a vonzó prémiumrendszer alkalmazása lehet a jó megoldás. Több foglalkoztató már az utánpótlás kinevelésében látja többek között a kiutat a hiányból. Ezt saját erőből megoldva, a szervezeti keretek között múködő képzési rendszerek megvalósításában gondolják, illetve a külső források bevonásával, vagyis az oktatási intézményekkel együttmúködve, és esetleg a közös szakképzési fejlesztési megoldásokkal. Ezt szolgálhatja tovább a karrier és utánpótlási menedzsment program, amely viszonylag kevés munkáltatónál valósul meg. Az atipikus foglalkoztatási lehetőségek, habár az okok között közepesként jelentkezett, csak igen szűk körűek a foglalkoztatóknál. Igaz, a rugalmas munkaidővel azért gyakrabban számolhatnak, mint lehetőséggel, a munkavállalók.

\section{Következtetések - konklúziók}

A szerzők egy 2017-es empirikus kutatás néhány eredményét mutatták be, amely vizsgálat többek között arra irányult, hogy magyarázatot keressen arra, mi vagy mik lehetnek az okai annak, hogy a felsőfokú végzettséggel rendelkezők közül kevesebben választják a közszférát, mint amennyit a munkáltatók szeretnének. A vizsgálati eredmények azt támasztják alá, hogy alapvetően a financiális indokokkal lehet magyarázni, hogy nincs elegendő ilyen jelentkező. Másodsorban a más területről érkező ajánlatok sokkal csábítóbbak lehetnek, amelyek elvonzzák a lehetséges munkavállalókat. Ezen eredmények alapján a szerzők a megfogalmazott hipotézist elfogadják.

Ugyanakkor azt is látni kell, hogy a munkáltatók tisztában vannak azzal, hogy a megoldás egyik alappillére a piacképes javadalmazás és juttatási rendszer megoldása, amellyel a válaszadók közül közel 9\% megpróbál is élni. Ám azt is figyelembe kell venni, hogy a hosszú távú megoldás lehet a financiális megoldásokon túl, a képzési rendszer összehangolása a közszféra igényeivel és a belső utánpótlás programok hatékony múködése és múködtetése.

Összességben a célunk az volt, hogy az elméletben felvázoltakat össze tudjuk hasonlítani a kutatásunkkal. Azaz, hogy a közszférában felmerülő fluktuáció és az ebből adódó munkaerőhiány milyen méreteket ölt Magyarországon. A szervezeteken belül elvégzett kutatás pontosabb képet adhat azokra az okokra, amelyek magához a fluktuációhoz vezetnek, tehát, hogy miért is elégedetlenek az alkalmazottak az adott munkahelyen. A legfőbb ok az elméletek alapján a közszférában egyértelműen az alacsony jövedelem és ezt a tényt a kutatásunk eredménye is teljes mértékben alátámasztja. $A z$ alacsony jövedelem járul hozzá leginkább az elégedetlen alkalmazottakhoz, így, ahhoz, hogy a munkaerőhiány minél nagyobb mértékét csökkenteni lehessen el és javuló tendenciát lehessen felmutatni a bérezést kellene emelni és kedvezőbb feltételeket kínálni az alkalmazottaknak. A bérezésen kívül számos más tényező is közrejátszik a fluktuáció növekedésében, mint a rossz munkakörülmények, az oktatási rendszer hiányosságai, a versenytársak közötti versengés a meglévő szabad munkaerőért a munkapiacon és előrelépési, fejlődési lehetőségek és programok hiánya. A szervezeteknek ezeket a fő problémaforrásokat kellene megvizsgálnia és elvégezni a szükséges intézkedéseket, hogy a problémát csökkenteni lehessen, valamint egy olyan rendszert kidolgozni, amely múködőképes és megvalósítható, mint a szervezet, mint az alkalmazott számára. 


\section{Felhasznált szakirodalom}

- Bagó J. (2018): A munkaerőhiány a mai Magyarországon. Opus et Educatio, 5. évfolyam 2. szám, 207-205.

- Balás E. (2018): Fluktuáció az önkormányzati hivataloknál. Comitatus. Önkormányzati Szemle, 28. évf. 229. sz. 94-102.

- Barrett, K., Greene, R. (2014): 3 Ways to Keep Public Employees from Leaving. In Governing. http://www.governing.com/columns/smart-mgmt/gov-in-and-out.html (Letöltve: 2019. 01.10.)

- Barrett, K., Greene, R. (2007): Why Do Employees Leave the Public Sector? In Governing. http://www.governing.com/columns/bg-report/Why-Do-Employees-Leave.html (Letöltve: 2019. 01.10.)

- Blooment-Bdo (2018): Jelentős munkaerőgondok Kelet-Közép- Európában. Tax [online] https://ado.hu/munkaugyek/bdo-jelentos-munkaerogondok-kelet-kozep-europaban/ (Letöltve: 2018. 12.17.)

- BBJ. (2018): Hungarians working abroad above EU average. In Budapest Business Journal (BBJ): [online] Available at:https://bbj.hu/analysis/hungarians-working-abroad-above-eu-average149883 (Letöltve: 2019.01.11.).

- Boudreau, W. J. (2010): Retooling HR- Using Proven Business Tools to Make Better Decisions About Talent. Boston: Harvard Business School Publishing Corporation.

- Carroll - Izard, D. M. (2016) Public Sector Leaders' Strategies to Improve Employee Retention. In Walden University ScholarWorks.

https://scholarworks.waldenu.edu/cgi/viewcontent.cgi?article=3260\&context=dissertations (Letöltve: 2019. 01.10.)

- Domokos, L., Jakovác, K., Németh, E. (2016): A közszféra munkaerőpiaci kihívásai. In Pénzügyi Szemle https://www.penzugyiszemle.hu/tanulmanyok-eloadasok/a-kozszferamunkaeropiaci-kihivasai (Letöltve: 2019. 01.10.)

- Gellén, M. (2013): A közszféra és a magánszféra viszonya az egyéni karrierutak tervezésében. In Researchgate.

https://www.researchgate.net/publication/304534308 A kozszfera es a maganszfera visz onya az egyeni karrierutak tervezeseben (Letöltve: 2019. 01.10.)

- Grissom, J. A.- Viano, L. S.-Selin, J. (2016): Understanding Employee Turnover in the Public Sector: Insights from Research on Teacher Mobility. Public Administration Review, 76 (2), 241251.

- Grissom, J. A.- Crotty, N. J., Keiser, L. (2016): Does My Boss's Gender Matter? Explaining Job Satisfaction and Employee Turnover in the Public Sector. In Journal of Public Administration Research and Theory. Volume 22, Issue 4, 1 October 2012, 649-673, https://doi.org/10.1093/jopart/mus004. (Letöltve: 2019. 01.10.)

- Groeneveld, S. (2011): Diversity and employee turnover in the Dutch public sector: Does diversity management make a difference? International Journal of Public Sector Management, Vol. 24 Issue: 6, pp.594-612.

- Hazafi Z. (2015): Néhány gondolat a közigazgatás munkaerő-piaci versenyképességéről. 25. szám, 12-20 
- Hír TV. (2018): 10 éve változatlan bérek, több ezer betöltetlen munkahely. In Hír TV. https://hirtv.hu/ahirtvhirei adattar/10-eve-valtozatlan-berek-tobb-ezer-betoltetlenmunkahely-2462726 (Letöltve: 2019. 01.19.)

- HRPortal (2018): Óriási munkaerőhiány, 10 éve változatlan bérek. https://www.hrportal.hu/hr/oriasi-munkaerohiany--10-eve-valtozatlan-berek-20180612.html (Letöltve: 2018. 12.22.)

- Izard-Caroll, M. (2016): Public Sector Leaders' Strategies to Improve Employee Retention. Walden University ScholarWorks.

- Kádár K.-Luksander A. - Szászné Fülöp N. (2018):Elemzés az aktivitási ráta alakulásáról. Állami Számvevőszék, Budapest.

- KSH (2018): A társadalmi haladás mutatószámrendszere Munkanélküliség (2003-2017) http://www.ksh.hu/thm/2/indi2 3 2.html (Letöltve: 2018. 12.17.)

- Linder V. (2014): Nemzetközi trendek a közszolgálatban; Jogi szabályozás és emberierőforrásgazdálkodási megoldások, Nemzeti Közszolgálati Egyetem (NKE): Budapest. http://m.ludita.uni-nke.hu/repozitorium/bitstream/handle/11410/8610/Teljes\%20sz\%C3\%B6veg\%21? sequence=1\&isAllowed=y (Letöltve: 2019. 01.10.)

- Mádi, L. (2018): Munkaerőpiac és munkanélküliség. In Magyar Idők. https://magyaridok.hu/velemeny/munkaeropiac-es-munkaerohiany-3678329/ (Letöltve: 2019. 01.19.)

- McGowan, A. M. - Andrews, D. (2015): „Skill Mismatch and Public Policy in OECD Countries”, OECD Economics Department Working Papers, No. 1210, OECD Publishing, Paris. http://dx.doi.org/10.1787/5js1pzw9Inwk-en (Letöltve: 2019. 01.10.)

- Miller, O. (2018): Employee Turnover in the Public Sector. Routledge, New York.

- Samuel, O. M., Chipunza, C. (2009): Employee retention and turnover: Using motivational variables as a panacea. African Journal of Business Management Vol.3 (8), pp. 410-415.

- Sebők, M. (2017): Munkaerőhiány és a munkaerő-mobilitás empirikus kutatása. In Tudásmenedzsment. A Pécsi Tudományegyetem Kultúratudományi, Pedagógusképző és Vidékfejlesztési Kar periodikája. XVIII. évfolyam 2. szám, 55-64.

- Schrale Á. (2016) Mennyit nőtt a foglalkoztatás 2008 óta Magyarországon? http://old.tarki.hu/hu/publications/SR/2016/03scharle.pdf (Letöltve: 2018. 12.17.)

- Selin, J. L. (2015): Understanding Employee Turnover in the Public Sector: Insights from Research on Teacher Mobility. Public Administration Review • Vol. 76, Issue 2, 241-251. (The American Society for Public Administration) DOI: 10.1111/puar.12435

- Székely, S. (2018): Özönleni kezdtek a külföldi munkavállalók Magyarországra. In Menedzsment fórum. [online] Available at: https://mfor.hu/cikkek/makro/ozonleni-kezdteka-kulfoldi-munkavallalokmagyarorszagra.html?utm source=rss\&amp;utm medium=referral (Letöltve: 2019.01.11).

- TASR (2019): Analytici: Trh práce by sa mohol v roku 2019 postupne uvol'ňovat́. In Trend. letöltés ideje 2018.12.10. https://www.etrend.sk/ekonomika/analytici-trh-prace-by-samohol-v-roku-2019-postupne-uvolnovat.html (Letöltve: 2019. 01.07.)

- Thomas, A. (2017): 5 Things Successful Companies Do to Retain Top Talent http://www.selectinternational.com/blog/bid/148239/5-things-successfulcompanies-do-toretain-top-talent (Letöltve: 2019. 01.07.)

- Žuffa, R. (2017): Ked' zamestnávatelom chýbajú l'udia. In Dennik SME. https://profit.sme.sk/c/20570719/ked-zamestnavatelom-chybaju-ludia.html (Letöltve: 2019. 01.08.) 